\title{
Occupational Safety Knowledge Management with Performance Indicators as a Strategy for the Reduction of Accidents in the Construction Sector in Mexico
}

\author{
Martha Patricia Quintero, Student \\ Juan Carlos Pérez, Project Director and Professor \\ Gerardo de Jesús López, Professor \\ Emmanuel Olivera, Professor \\ $\mathrm{PhD}$ in Strategic Planning and Technology \\ Universidad Popular Autónoma del Estado de Puebla, México
}

doi: 10.19044/esj.2017.v13n23p342 URL:http://dx.doi.org/10.19044/esj.2017.v13n23p342

\begin{abstract}
The construction industry is one of the key contributors to a country's economy. It accounts for $13.4 \%$ of total annual production. The construction sector has specific characteristics such as dynamic work and uncertain conditions; therefore, it tends to cause occupational accidents. Another one of its features is the temporary nature of its projects. This characteristic leads to the loss of learning and disappearance of workers at the end of each project inhibiting workers from gaining experience. The aim of this paper is to propose a model of knowledge management in occupational safety that limits or stops the loss of knowledge, covers the dynamic needs of the construction sector and helps to reduce accidents at work. The present research method is exploratory; it identifies the elements or strategies of the stages of knowledge management that allow the reduction of accidents in the construction sector. As a result of this research, the authors have proposed a model which is able to manage the knowledge generating learning from its elements. Some key safety performance indicators as strategies to reduce occupational accidents are discussed.
\end{abstract}

Keywords: Construction; Knowledge Management; Occupational Safety; Safety Performance Indicators

\section{Introduction}

The construction industry is one of the key contributors to a country's economy (Solís-Carcaño and Arcudia-Abad, 2011, p. 155). The global 
construction industry accounts for $13.4 \%$ of total annual production (Global Construction Perspectives and Oxford Economics, 2011, p. 6) and employs around $7 \%$ of the world's labor force. It is, however, also responsible for 30$40 \%$ of work-related deaths (Sunindijo and Zou, 2011, p. 605).

In industrialized countries, the construction industry employs 6 to $10 \%$ of the labor force and accounts for 20 to $40 \%$ of fatalities at work; in underdeveloped countries, there is a similar propensity, and some instances are worse than the ones in industrialized nations (Ranheem and Hinze, 2014, p. 276).

The construction industry has a high incidence rate in the world. In 2014, Hong Kong had a 41.9 accident rate per 1,000 workers (Occupational Safety and Health Branch Labor Department, 2015, p. 2). In Mexico, the construction sector has the highest number of labor related deaths, and it had an accident rate of 2.0 per 10,000 workers in 2015 (IMSS, 2015).

The characteristics of the construction sector are its dynamic nature (Swueste, Frijters, and Guldenmund, 2012, p. 1334), uncertain conditions (Gurcanli, and Mungen,_2009, p. 372), hazardous features and unpredictable changes (Maryani, Wignjosoebroto, and Partiwi, 2015, p. 392).

In the construction sector, the work is mainly through projects. Projects are transitional. The knowledge and experience are lost when projects finish (Esmi, and Ennals, 2009, p. 197). The lack of knowledge management in safety causes lost knowledge (Grover, and Frose, 2016, p. 1283). The missed opportunities for learning trigger reoccurring accidents (Gressrgard, 2014, p. 53; Sabran, March 2016, p. 1180). Knowledge management in construction projects avoids the repetition of accidents through registration and documentation of the efficient way of performing a job.

Only one previous study exists which proposes strategies to improve the knowledge management in occupational safety in the construction sector presented as a case study (Hallowell, 2011, p. 210). The papers related to the management of occupational safety knowledge presented in the literature did not show the required elements in each stage of knowledge management (Grover and Froese, 2016, p. 1283; Shirouyehzad, Mokhatab, and Berjis, 2017 , p. 77), and those papers were not related to the construction sector.

Knowledge management is an intangible asset (Dickel and De Moura, 2016 , p. 212) and a necessary element to improve, formalize and automate an organization (Chang, 2015, p. 434). The objective of knowledge management is to make the correct decisions that allow organizations to gain a competitive advantage (Kebede, 2010, p. 421); as a result, knowledge management is a key factor for global guidelines (Dickel and De Moura, 2016, p. 211).

The causes of most workplace accidents in the construction industry are negligent management (Cheng, Leu, Lin and Fan, 2010, p. 701), lack of 
workers' capacity to assess risks, lack of supervision and loss of control at the worksite (Titas, 2013, p. 239; Cheng et al., 2010, p. 703-704).

A cause of accidents in the construction sector in Mexico is that workers have reduced the culture of awareness toward safety; consequently, they do not take the necessary precautions in their work activities. Furthermore, they do not consider themselves capable of preventing an accident, and they have received little or in some cases no training in their work life about job safety (Solís-Carcaño and Arcudia-Abad, 2011, p. 161).

A construction worker in Mexico must have knowledge of the proper handling of hazardous chemicals, safety knowledge to provide maintenance or repair in contaminated atmospheres as well as knowledge of the safe use of mobile equipment (Solís-Carcaño and Arcudia-Abad, 2011, p. 161).

Organizations with lower accident rates are characterized by occupational safety and health communication between workers and supervisors every day, regular safety inspections, higher priority on safety at meetings and decisions concerning labor practices, through accident investigation and finally empowerment of workers (Vinodkumar and Bhasi, 2010, p. 2083).

The safety strategies that help to reduce labor related accidents in the construction industry are near miss reports, audit programs, supplier safety inspections, behavior-based observation (Hallowell, Hinze, Baud and Wehle, 2013, p. 04013010-5), workers' participation in perception surveys, the involvement of every contractor in safety meetings, a worker to worker observation program (Hinze, Hallowell and Baud, 2013, p. 04013006-6) and job safety analysis (Hallowell, 2011, p. 209).

Safety indicators are tools to encourage individuals to work safely, monitor and provide information on organizational performance and increase organizational safety potential (Reiman and Pietikainen, 2012, p. 1994).

Safety indicators are divided into lagging indicators and leading indicators. Sinelnikov, Inouye, and Kerper (2015) have described both lagging indicators and leading indicators. Lagging indicators are the basis for organizations to assess occupational safety performance such as injury and mortality rates. However, lagging indicators are considered to be of little use because they measure the failure or damage already caused. Leading indicators inform preventively of an accident in an attempt to avoid it. (p. 241 - 242).

Meanwhile, Hopkins (2009) describes leading indicators as active and lagging indicators as reactive. (p. 462). Knegtering and Pasman (2009), as well as Zwetsloot (2009), defined leading indicators as a quality measure for system management and lagging indicators as precursors to the loss of control of incidents. (p. 165; p. 496). 
Researchers have identified the types of safety performance indicators. Some leading indicators are behavior-based observations, near accidents, audits, training, meeting, incident investigation (Sinelnikov et al. 2015, p. 243) and benchmarking (Hohn and Duden, January 2009, p. 4).

Other researchers have considered safety systems, management and leadership committees, occupational safety and health inspections and audits, consultation and communication about OSH (Shea, De Cieri, Donohue, Cooper, and Sheehan, 2016, p. 294; Sheehan, Donohue, Shea, Cooper, and De Cieri, 2016, p. 130) and job safety analysis (Rozenfeld, Sacks, Rosenfeld, and Baum, 2010, p. 491; Lingard, Hallowell, Salas, and Pirzadeh, 2017, p. 210) as leading indicators.

Lagging indicators are accidents, injuries or damage (Christian, Bradley, Wallace and Burke, 2009, p. 1107; Sinelnikov et al., 2015, p. 241).

The learning from accidents and incidents is a fundamental element in the safety performance by avoiding the same flaws that caused the accident (Lindberg, Hansson and Rollenhagen, 2010, p. 714). Learning from accidents is to acquire, examine and communicate the knowledge they have generated (Lindberg et al., 2010, p. 714).

Learning from incidents and the exchange of information among construction workers reduces the probability and severity of occupational accidents (Goh and Chua, 2013, p. 460). Inexperienced workers demonstrate behaviors which do not assess the risks to that of which they are exposed to in the workplace (Cooper, 2001, p. 215).

Drupsteen and Wybo (2015), state that there are two learning processes: learning from weak signals and learning from incidents. Therefore, it requires gathering and detecting information in a different way for efficient use that allows learning from it. (p. 31).

At one end, the weak or alert signals for the first stage of the Drupsteen and Wybo Model (2015) must be detected, interpreted, transmitted and prioritized. Furthermore, incidents or accidents should be reported, investigated and prioritized. Subsequent stages are similar for weak signals and events which are to investigate, follow up and finally evaluate. (p. 31).

The analysis of weak signals is a useful factor in knowledge management (Kaivo-oja, 2012, p. 206). Occupational safety management must "identify weak signals and interpret early warnings" to stop risk from continually becoming a disaster (Macrae, 2014, p. 2).

The objective of this research is to propose a model of occupational safety knowledge management that avoids the loss of knowledge, covers the dynamic needs of the construction sector and helps to reduce work accidents. 


\section{Method}

The present investigation was exploratory. The search focused on work accidents. The research was carried out with a vision from the general to the particular. During the inquiry process, it identified that the construction industry is one of the sectors with the highest accident rates.

It detected that one of the causes of accidents in the construction sector is due to the lack of knowledge management. The literature review showed that there is a lack of research in the elements of the stages of knowledge management in occupational safety.

The research identified strategies or elements of the stages of knowledge management that allow the reduction of accidents in the construction sector. It discovered that some items of the stages of knowledge management are performance safety indicators.

The following databases have been used to obtain an overview of the available literature: Elsevier, ASCE, Emeralda, Taylor \& Francis, Wiley, among others. Different journals were referenced such as Safety Science, Accident Analysis, and Prevention, Journal of Management in Engineering, Journal of Knowledge Management, Professional Safety, Construction Management and Economics, Journal of Loss Prevention in the Process Industries, Journal of Safety Research, Procedia Engineering and Procedia Manufacturing.

Searches focused on titles, keywords, abstracts and latest publications. The search strings used were knowledge management, knowledge management in occupational safety and health, knowledge management in the construction sector, occupational safety in the construction industry Mexico and safety performance indicators: leading indicators, lagging indicators and learning experience. The articles were analyzed and categorized according to their main subjects. Finally, the model was structured identifying the necessary elements of each stage.

Different countries have investigated the lines of research addressed in this project. Safety in the construction sector has been the topic of a study in the United States, Indonesia, United Kingdom, Mexico, Netherlands, among others due to the high global accident rate in the construction sector.

In one case, the management of knowledge in the construction sector has been studied in the United Kingdom. In another instance, safety knowledge management has been examined in the United States, Malaysia, and Iran. Moreover, learning from experience has been analyzed in Germany and France. 


\section{Results}

The present research is the first part of a project that has been carried out, which shows, as a result, the model for the knowledge management of occupational safety in the construction sector.

The project emerges from the interest of knowledge management of occupational safety in the construction sector. The model consists of three stages of knowledge management (Figure 1). They are knowledge acquisition, knowledge transfer and application and finally knowledge storage (Alavi and Leidner, 2001, p. 115; Svetlik and Stavrou-Costea, 2007, p. 200-201).

In the first stage, the proposal is to acquire knowledge from external and internal sources.

Of the external sources, the legal aspect considered was STPS, which is a required source in Mexico. However, this proposed model considered other optional international safety agencies in the construction sector like OSHA and AGC of America. Furthermore, it consulted technical data sheets from suppliers of tools, machinery, and equipment, material safety data sheets from suppliers of materials and finally updated information through academic publications and occupational safety benchmarking.

Referring to internal sources, the model proposes to acquire information and generate learning through the experience of the safety performance indicators marked in the literature. Accidents are the lagging indicators (Christian et al., 2009, p. 1107; Sinelnikov et al., 2015, p. 241). Moreover, the leading indicators are near accidents (Sinelnikov et al., 2015, p. 241), behavior-based observations, (Jasiulewicz-Kaczmakek, Szwedzka, and Szczuka, 2015, p. 4878; Sinelnikov et al., 2015, p. 243) and selfinspections (Shea et al., 2016, p. 296; Papazoglou, Aneziris, Bellamy, Ale, and Oh, 2017, p. 162; Yamin, Parker, Xi and Stanley, 2017, p. 1).

This proposal applies the Drupsteen (2015) sequence of learning from experience for knowledge acquisition. Accidents considered to be lagging indicators must be reported, investigated and prioritized. Leading indicators such as near accidents, behavior-based observations and self-inspections of the tools, machinery, and equipment must be detected, interpreted and prioritized to detect weak signals and alarms. (p. 31).

The transfer and application stage has been determined to be the second stage because the transfer of knowledge in the construction sector is passive and few workers consult the stored information (Hallowell, 2011, p. 205).

For the second stage, of transfer and application, the proposal is to create four tools through the use of work teams. Communities of practice (CoPs) is one of the most used work groups by the construction sector (Tan et al., 2011, p. 339). 
The CoPs support the exchange of knowledge and the generation of new knowledge through the collaboration of the members of the organization (Kaivo-Oja, 2012, p. 214). The CoPs should be constituted by the foreman, the safety leader, the site manager and the suppliers of materials, tools, machinery and equipment.

The safety tools are job safety analysis, which provides, as a result, safe work procedures, behavior-based safety, planned self-inspections of tools, machinery and equipment and finally a layout of occupational safety critical control points (LOSCCP). These tools will analyze and evaluate the risks, which are indicated in the model of learning from experiences (Drupsteen and Wybo, 2015, p. 31).

From this model, the concept of occupational safety critical control points (OSCCP) emerges from the System Hazard Analysis and Critical Control Points (HACCP). HACCP is a tool that ensures the safety of food production (El-Hofi, El-Tanboly, and Ismail, 2010, p. 332). The Critical Control Point (CCP) is "a practical place, procedure or process that can be controlled to prevent, eliminate or reduce the risk to acceptable levels" (Cusato, Tavolaro, and de Oliveira, 2012, p. 22).

In this paper, occupational safety critical control points (OSCCP) are places where risks increase in the construction sector. The occupational safety critical control points are the identification of locations where the operation of multiple pieces of mobile equipment and worker activities combine (Marks and Teizer, 2013, p. 636), and simultaneous work at different floor levels in the same job area occurs (Manu, Ankrah, Proverbs, and Suresh, 2010, p. 689). This manuscript proposes to elaborate a lay out with OSCCP every time the civil work advances in the project.

For the knowledge application stage, it is necessary to implement those generated tools: the safe work procedures, the behavior-based safety, planned self-inspections of tools, machinery, and equipment as well as the lay out of the OSCCP to detect weak signals. If these instruments fail, there will be accidents again which will serve as feedback for learning. This process provides the opportunity to follow the learning to generate experiences (Drupsteen, 2015, p. 31).

During the same stage, the elaborated tools will be communicated since communication is an indispensable component in knowledge management (Uslu, and Çubuk, 2015, p. 407). The media has been divided into two sections because workers and low-level staff rarely consult the information required online (Hallowell, 2011, p. 205) and the lack of communication in the construction sector in Mexico has been a cause of accidents (Solís-Carcaño and Franco-Poot, 2014, p. 10).

The elaborated tools will be shared with the workers through communication boards, newsletters, formal/informal communication 
between employees and to other interested parties with access to digital information via safety intranet, electronic feedback systems and open forums with commentary or safety troubleshooting.

Finally, the last stage, the information storage will be in the safety department for print media and the intranet system of safety for digital media.

Figure 1. The Proposed Model of Knowledge Management of Occupational Safety for the Construction Sector in Mexico.

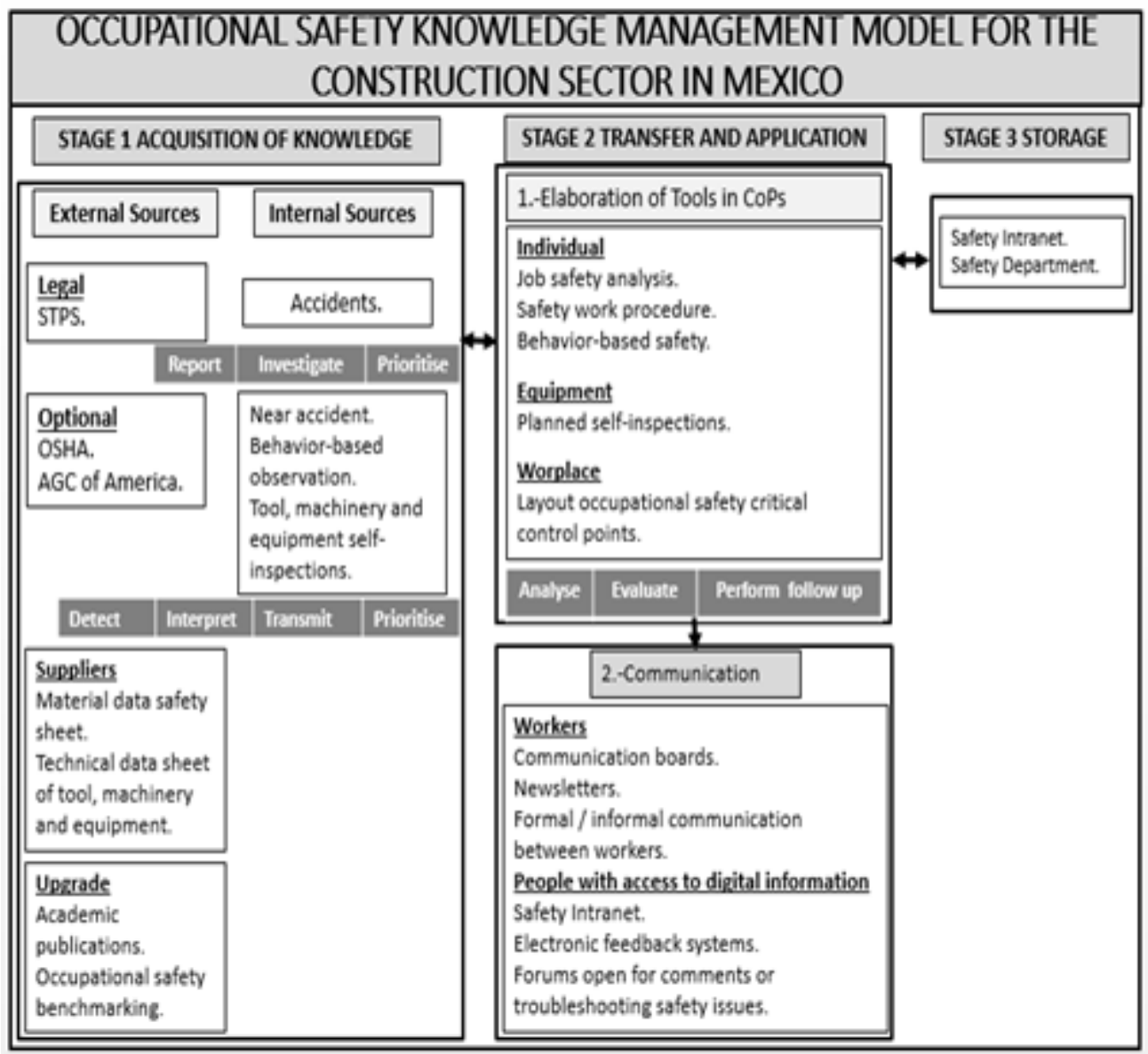

Source: Authors, 2017.

\section{Discussion}

The elements of knowledge management in occupational safety that can avoid the loss of knowledge, cover the dynamic needs of the construction and influence the reduction of work accidents were identified through literary review (Table 1). It found that some of these elements are indicators of safety performance, where it is proposed to learn from them, based on the model of learning with a tendency to experience (Drupsteen and Wybo, 2015, p. 31). 
Table 1. Strategies for Occupational Safety Knowledge Management to Cover the Objective of this Paper.

\begin{tabular}{|c|c|c|c|c|}
\hline Strategy & $\begin{array}{l}\text { Avoid loss of } \\
\text { Knowledge }\end{array}$ & $\begin{array}{c}\text { Cover the } \\
\text { dynamics needs }\end{array}$ & $\begin{array}{l}\text { Avoid the } \\
\text { occupational } \\
\text { accidents }\end{array}$ & $\begin{array}{c}\text { Safety } \\
\text { performance } \\
\text { indicators }\end{array}$ \\
\hline STPS & & & $\begin{array}{c}\mathrm{X} \\
(\mathrm{STPS}, 2011, \text { p. 2) }\end{array}$ & \\
\hline OSHA & & & $\begin{array}{c}\text { X } \\
\text { (OSHA, 1990, p. 3; } \\
\text { OSHA, 2011, p. 1) }\end{array}$ & \\
\hline AGC of America & & & $\begin{array}{c}\text { X } \\
\text { (Hallowell, 2011, p. } \\
\text { 209) }\end{array}$ & \\
\hline $\begin{array}{l}\text { Material safety data } \\
\text { sheets }\end{array}$ & & & $\begin{array}{c}\text { X } \\
\text { (Nicol, Hurrell, } \\
\text { Wahyuni, } \\
\text { McDowall, and } \\
\text { Chu, 2008, p. 861- } \\
\text { 862). }\end{array}$ & \\
\hline $\begin{array}{c}\text { Technical data } \\
\text { sheets of equipment }\end{array}$ & & & $\begin{array}{c}\mathrm{X} \\
\text { (INSHT, 2016, p. 1) }\end{array}$ & \\
\hline $\begin{array}{l}\text { Academic } \\
\text { publications }\end{array}$ & & & $\begin{array}{c}\mathrm{X} \\
\text { (Hallowell, 2011, p. } \\
\text { 207) }\end{array}$ & \\
\hline $\begin{array}{c}\text { Occupational safety } \\
\text { benchmarking }\end{array}$ & & & $\begin{array}{c}\text { X } \\
\text { (Hohn and Duden, } \\
\text { 2009, p. 4; } \\
\text { Saunders, McCoy, } \\
\text { Kleiner, Lingard, } \\
\text { Cooke, Mills, and } \\
\text { Wakefield, 2016, p. } \\
\text { 926) }\end{array}$ & $\begin{array}{c}\text { X } \\
\text { (Hohn and Duden, } \\
\text { 2009, p. 4) }\end{array}$ \\
\hline Accident reports & $\begin{array}{c}\text { X } \\
\text { (Lindberg et al., } \\
\text { 2010, p. 714; } \\
\text { Salguero-Caparros, } \\
\text { Suarez-Cebador, } \\
\text { and Rubio-Romero, } \\
\text { 2015, p. 329) }\end{array}$ & & $\begin{array}{c}\text { X } \\
\text { (Lindberg et al., } \\
\text { 2010, p.714; } \\
\text { Salguero-Caparros, } \\
\text { et al., 2015, p. 329) }\end{array}$ & $\begin{array}{c}\text { X } \\
\text { (Christian et al., } \\
\text { 2009, p.1104; } \\
\text { Pawłowska, Z. } \\
\text { 2015, p. 284) }\end{array}$ \\
\hline $\begin{array}{l}\text { Near-accident } \\
\text { reports }\end{array}$ & $\begin{array}{c}\text { X } \\
\text { (Chua, and Goh, } \\
\text { 2004, p. 543; Goh } \\
\text { and Chua, 2013, p. } \\
\text { 460) }\end{array}$ & & $\begin{array}{c}\text { X } \\
\text { (Goh and Chua, } \\
\text { 2013, p. 466; } \\
\text { Hallowell et al., } \\
\text { 2013, p. 04013010- } \\
\text { 5) }\end{array}$ & $\begin{array}{c}\text { X } \\
\text { (Sinelnikov et al., } \\
\text { 2015, p. 241) }\end{array}$ \\
\hline
\end{tabular}




\begin{tabular}{|c|c|c|c|c|}
\hline $\begin{array}{c}\text { Behavior based } \\
\text { Safety/ behavior- } \\
\text { based observations }\end{array}$ & $\begin{array}{c}\text { X } \\
\text { (Jasiulewicz- } \\
\text { Kaczmakek et al., } \\
\text { 2015, p. 4877) }\end{array}$ & $\begin{array}{c}\text { X } \\
\text { (Jasiulewicz- } \\
\text { Kaczmakek et al., } \\
\text { 2015, p. 4878) }\end{array}$ & $\begin{array}{c}\text { X } \\
\text { (Ismail, Hashim, } \\
\text { Zuriea, Ismail, } \\
\text { Kamarudin, and } \\
\text { Baharom, 2012, p. } \\
\text { 587; Hallowell et } \\
\text { al., 2013, p. } \\
\text { 04013010-5; Hinze } \\
\text { et al., 2013, p. } \\
\text { 04013006-6; Li, Lu, } \\
\text { Hsu, Gray and } \\
\text { Huang, 2015, p. } \\
\text { 108) }\end{array}$ & $\begin{array}{c}\text { X } \\
\text { (Jasiulewicz- } \\
\text { Kaczmakek et al., } \\
\text { 2015, p. 4878; } \\
\text { Sinelnikov et al., } \\
\text { 2015, p. 243) }\end{array}$ \\
\hline Self-inspections & & $\begin{array}{c}\text { X } \\
\text { (Yamin et al., 2017, } \\
\text { p. 1) }\end{array}$ & $\begin{array}{c}\text { X } \\
\text { (Hallowell et al., } \\
\text { 2013, p. 04013010- } \\
\text { 5; Yamin et al., } \\
\text { 2017, p. 1) }\end{array}$ & $\begin{array}{c}\text { X } \\
\text { (Shea et al., 2016, } \\
\text { p. 296; Papazoglou } \\
\text { et al., 2017, p. 162; } \\
\text { Yamin et al., 2017, } \\
\text { p. 1) }\end{array}$ \\
\hline Job Safety Analysis & $\begin{array}{c}\text { X } \\
\text { (Rozenfeld et al., } \\
\text { 2010, p. 491) }\end{array}$ & & $\begin{array}{c}\mathrm{X} \\
\text { (Glenn, 2011, p. 48; } \\
\text { Hallowell, 2011, p. } \\
\text { 209; Ismail et al., } \\
\text { 2012, p. 590) }\end{array}$ & $\begin{array}{c}\text { X } \\
\text { (Rozenfeld et al., } \\
\text { 2010, p. 491; } \\
\text { Lingard et al., } \\
\text { 2017, p. 210) }\end{array}$ \\
\hline Communications & $\begin{array}{c}\text { (Vinodkumar and } \\
\text { Bhasi, 2010, p. } \\
\text { 2091) }\end{array}$ & & $\begin{array}{c}\mathrm{X} \\
\text { (Vinodkumar and } \\
\text { Bhasi, 2010, p. } \\
\text { 2083) }\end{array}$ & $\begin{array}{c}\text { X } \\
\text { (Shea et al., 2016, } \\
\text { p. 296; Sheehan et } \\
\text { al., 2016, p. 130) }\end{array}$ \\
\hline
\end{tabular}

Source: Authors, 2017.

In contrast to other articles, safety performance indicators were classified as lagging indicators and leading indicators to learn from them.

In this model, a new concept has emerged. The new concept is occupational safety critical control points (OSCCP). In this paper, the OSCCP are places where risks increase during the process of the construction project. In identifying OSCCPs before the working day, all workers involved in this area can be informed of the activities and risks that they are exposed to so they can work preventively.

The stages of the knowledge management model in occupational safety can be used as a systematic plan to reuse information and learn from injuries considering past projects. The limitation of the model is not having specified the size of the company and the type of project to which it can be applied to in the construction sector.

\section{Conclusion}

The construction sector has one of the highest incidence rates. The lack of knowledge management is one of the causes of accidents in the construction industry. There is only one study that has proposed strategies 
for the improvement of knowledge management in occupational safety in the construction industry, and this research was carried out by Hallowell as a case study (Hallowell, 2011, p. 210).

This model proposes to acquire information and generate knowledge to stop the recurrence of accidents and avoid the loss of learning after each project. This paper clarifies the elements of occupational safety required in each stage of knowledge management in the construction sector. Some of the items are occupational safety performance indicators: leading and lagging. These items may need further attention in both research and practice.

The OSCCP is a new concept. This idea emerges in this paper. The OSCCP identifies the dangerous places when there is combined worker activities or operation of mobile equipment at the same time; congestion of the worksite is one of the reasons for accidents in this sector (Manu et al., 2010, p. 688).

The proposed occupational safety critical control points arise from the identification of fatal accidents in the construction sector; approximately $21 \%$ of fatal accidents resulted from workers being struck by an object or some piece of construction equipment (Marks and Teizer, 2013, p. 637).

The model can be applied as a step-by-step guide to obtain knowledge. The first stage identifies internal and external sources to acquire the necessary knowledge in the construction sector. The second stage has the purpose of transforming tacit knowledge into explicit knowledge through CoPs, with the elaboration of JSA, BBS, planned inspections and layout of occupational safety critical control points. The next stage transfers explicit knowledge of occupational safety. It is based on explicit knowledge since it is more useful than tacit knowledge (Hallowell et al., 2011, p. 209).

Finally, in the third stage, the information must be available to interested parties through print media stored in the safety department and through digital media on the intranet.

\section{References:}

1. Alavi, M., and Leidner, D. E. (2001). Review: Knowledge management and knowledge management systems: Conceptual foundations and research issues. MIS quarterly, 107-136.

2. Chang, C. L. H., \& Lin, T. C. (2015). The role of organizational culture in the knowledge management process. Journal of Knowledge Management, 19(3), 433-455.

3. Cheng, C. W., Leu, S. S., Lin, C. C., and Fan, C. (2010). Characteristic analysis of occupational accidents at small construction enterprises. Safety Science, 48(6), 698-707. 
4. Christian, M. S., Bradley, J. C., Wallace, J. C., and Burke, M. J. (2009). Workplace safety: a meta-analysis of the roles of person and situation factors. Journal of Applied Psychology, 94(5), 1103-1127.

5. Chua, D. K., \& Goh, Y. M. (2004). Incident causation model for improving feedback of safety knowledge. Journal of Construction Engineering and Management, 130(4), 542-551.

6. Cooper, D., (2001). Improving safety culture: a practical guide. Applied Behavioural Sciences. Recuperado de: http://behaviouralsafety.com/articles/Improving_safety_culture_a_practical_guide.pdf

7. Cusato, S., Tavolaro, P., \& de Oliveira, C. A. F. (2012). Implementation of Hazard Analysis and Critical Control Points System in the Food Industry: Impact on Safety and the Environment. Novel Technologies in Food Science, 21-37.

8. Dickel, D. G., and de Moura, G. L. (2016). Organizational performance evaluation in intangible criteria: a model based. RAI Revista de Administração e Inovação, (13) 211-220.

9. Drupsteen, L., and Wybo, J. L. (2015). Assessing propensity to learn from safety-related events. Safety Science, 71, 28-38.

10. El-Hofi, M., El-Tanboly, E. S., and Ismail, A. (2010). Implementation of the Hazard Analysis Critical Control Point (HACCP) system to UF white cheese production line. Acta Scientiarum Polonorum Technologia Alimentaria, 9(3), 331-342.

11. Esmi, R., and Ennals, R. (2009). Knowledge management in construction companies in the UK. AI \& Society, 24(2), 197-203.

12. Glenn D., 2011. Job safety analysis is Its Role Today. ProfessionalSafety. 48-57.

13. Global Construction Perspectives and Oxford Economics. (2009). Global construction 2020 A Global forecast for the construction industry over the next decade to 2020. Oxford Economics, London. Recuperado de https://wcoeusa.org/sites/default/files/RICSGlobalConstructionForec ast2020\%5B1\%5D.pdf

14. Goh, Y. M., \& Chua, D. (2013). Neural network analysis of construction safety management systems: a case study in Singapore. Construction Management and Economics, 31(5), 460470.

15. Gressgård, L. J. (2014). Knowledge management and safety compliance in a high-risk distributed organizational system. Safety and health at work, 5(2), 53-59.

16. Grover, R., and Froese, T. M. (2016). Knowledge Management in Construction Using a SocioBIM Platform: A Case Study of AYO Smart Home Project. Procedia Engineering, 145, 1283-1290. 
17. Gürcanli, G. E., and Müngen, U. (2009). An occupational safety risk analysis method at construction sites using fuzzy sets. International Journal of Industrial Ergonomics, 39(2), 371-387.

18. Hallowell, M. R. (2011). Safety-knowledge management in American construction organizations. Journal of Management in Engineering, 28(2), 203-211.

19. Hallowell, M. R., Hinze, J. W., Baud, K. C., \& Wehle, A. (2013). Proactive construction safety control: Measuring, monitoring, and responding to safety leading indicators. Journal of Construction Engineering and Management, 139(10), 04013010-1-04013010-8.

20. Hinze, J., Hallowell, M., \& Baud, K. (2013). Construction-safety best practices and relationships to safety performance. Journal of Construction Engineering and Management, 139(10), 04013006-104013006-8.

21. Hohn, T., and Duden, D. (January, 2009). Benchmarking your Leading Safety Indicators to Manage Jobsite Risk. Professional Development Conference and Exhibition. American Society of Safety Engineers, 1-7.

22. Hopkins, A., (2009). Thinking about process safety indicator. Safety Science 47 (4), 460-465.

23. IMSS (Instituto Mexicano del Seguro Social). (2015). Memoría estadística 2015. Instituto Mexicano del Seguro Social. Recuperado de http://www.imss.gob.mx/conoce-al-imss/memoria-estadistica2015.

24. Ismail, F., Hashim, A. E., Zuriea, W., Ismail, W., Kamarudin, H., \& Baharom, Z. A. (2012). Behaviour based approach for quality and safety environment improvement: Malaysian experience in the oil and gas industry. Procedia-Social and Behavioral Sciences, 35, 586-594.

25. INSHT (Instituto Nacional de Seguridad e Higiene en el Trabajo). (2016). Notas Técnicas de Prevención, Grúas móviles autopropulsadas: seguridad. Instituto Nacional de Seguridad e Higiene en el Trabajo. Recuperado de http://insht.es/InshtWeb/Contenidos/Documentacion/NTP/NTP/Fiche ros/1066a1077/ntp-1077.pdf

26. Jasiulewicz-Kaczmarek, M., Szwedzka, K., \& Szczuka, M. (2015). Behaviour based intervention for occupational safety-case study. Procedia Manufacturing, 3, 4876-4883.

27. Kaivo-oja, J. (2012). Weak signals analysis, knowledge management theory and systemic socio-cultural transitions. Futures, 44(3), 206217. 
28. Kebede, G. (2010). Knowledge management: An information science perspective. International. Journal of Information Management, 30(5), 416-424.

29. Knegtering, B., and Pasman, H. J. (2009). Safety of the process industries in the 21st century: a changing need of process safety management for a changing industry. Journal of Loss Prevention in the Process Industries, 22(2), 162-168.

30. Li, H., Lu, M., Hsu, S. C., Gray, M., and Huang, T. (2015). Proactive behavior-based safety management for construction safety improvement. Safety Science, 75, 107-117.

31. Lindberg, A. K., Hansson, S. O., and Rollenhagen, C. (2010). Learning from accidents-what more do we need to know?. Safety Science, 48(6), 714-721.

32. Lingard, H., Hallowell, M., Salas, R., \& Pirzadeh, P. (2017). Leading or lagging? Temporal analysis of safety indicators on a large infrastructure construction project. Safety science, 91, 206-220.

33. Macrae, C. (2014). Early warnings, weak signals and learning from healthcare disasters. BMJ quality and safety, 23, 1-6.

34. Manu P., Ankrah n., Proverbs D., Suresh S. (2010). An approach for determining the extent of contribution of construction Project feature to accident causation. Safety Science 48(1), 687-692.

35. Marks, E. D., and Teizer, J. (2013). Method for testing proximity detection and alert technology for safe construction equipment operation. Construction Management and Economics, 31(6), 636646.

36. Maryani, A., Wignjosoebroto, S., \& Partiwi, S. G. (2015). A system dynamics approach for modeling construction accidents. Procedia Manufacturing, 4, 392-401.

37. Nicol, A. M., Hurrell, A. C., Wahyuni, D., McDowall, W., \& Chu, W. (2008). Accuracy, comprehensibility, and use of material safety data sheets: A review. American journal of industrial medicine, 51(11), 861-876.

38. Occupational safety and health branch labor department, (August, 2015). Occupational safety and health statistics bulletin. Issue 15. Hong Kong. Recuperado de: http://www.labour.gov.hk/eng/osh/pdf/Bulletin2014.pdf

39. OSHA (Occupational Safety and Health Administration). (2011). Construction focus four: Outreach training packet. OSHA Directorate of Training and Education, Washington, DC.

40. OSHA. (Occupational Safety and Health Administration) (1990). Analysis of construction fatalities. The OSHA data base 1985-1989. Washington, D.C. 
41. Papazoglou, I. A., Aneziris, O. N., Bellamy, L. J., Ale, B. J. M., and Oh, J. (2017). Quantitative occupational risk model: Single hazard. Reliability Engineering \& System Safety, 160, 162-173.

42. Pawłowska, Z. (2015). Using lagging and leading indicators for the evaluation of occupational safety and health performance in industry. International journal of occupational safety and ergonomics, 21(3), 284-290.

43. Raheem, A.A., \& Hinze, J.W. (2014). Disparity between construction safety standards: A global analysis. Safety Science, 70, 276-287.

44. Reiman, T., Pietikäinen, E. (2012). Leading indicators of system safety-monitoring and driving the organizational safety potential. Safety Science 50 (10), 1993-2000.

45. Rozenfeld, O., Sacks, R., Rosenfeld, Y., \& Baum, H. (2010). Construction job safety analysis. Safety science, 48(4), 491-498.

46. Sabran, A. S. H. (March, 2016). Knowledge Management in Human Error in Accident Prevention. Proceedings of the 2016 International Conference on Industrial Engineering and Operations Management. Society International, Kuala Lumpur, Malaysia, 1180-1191.

47. Salguero-Caparros, F., Suarez-Cebador, M., \& Rubio-Romero, J. C. (2015). Analysis of investigation reports on occupational accidents. Safety science, 72, 329-336.

48. Saunders, L. W., McCoy, A. P., Kleiner, B. M., Lingard, H., Cooke, T., Mills, T., \& Wakefield, R. (2016). International benchmarking for performance improvement in construction safety and health. Benchmarking: An International Journal, 23(4), 916-936.

49. Shea, T., De Cieri, H., Donohue, R., Cooper, B., and Sheehan, C. (2016). Leading indicators of occupational health and safety: An employee and workplace level validation study. Safety Science, 85, 293-304.

50. Sheehan, C., Donohue, R., Shea, T., Cooper, B., and De Cieri, H. (2016). Leading and lagging indicators of occupational health and safety: The moderating role of safety leadership. Accident Analysis and Prevention, 92, 130-138.

51. Shirouyehzad, H., Mokhatab Rafiee, F., and Berjis, N. (2017). Performance evaluation and prioritization of organizations based on knowledge management and safety management approaches using DEA, a case study. Journal of Modelling in Management, 12(1), 7795.

52. Sinelnikov, S., Inouye, J., and Kerper, S. (2015). Using leading indicators to measure occupational health and safety performance. Safety Science, 72, 240-248. 
53. Solís-Carca, R. G., and Franco-Poot, R. J. (2014). Construction workers' perceptions of safety practices: A case study in Mexico. Journal of Building Construction and Planning Research, 2(1), 1-11.

54. Solís-Carcaño, R. G., and Arcudia-Abad, C. E. (2011). Constructionrelated accidents in the Yucatan Peninsula, Mexico. Journal of Performance of Constructed Facilities, 27(2), 155-162.

55. Spear, J., (2010). Measuring safety and health performance: a review of commonly used performance indicators. Jerome E. Spear Consulting, 1-6.

56. STPS, 2011. NOM-031-STPS-2011, Construcción-Condiciones de seguridad y salud en el trabajo. Secretaría del Trabajo y Previsión Social. Recuperado de http://www.stps.gob.mx/bp/secciones/dgsst/normatividad/normas/No m-031.pdf

57. Sunindijo, R. Y., \& Zou, P. X. (2011). Political skill for developing construction safety climate. Journal of Construction Engineering and Management, 138(5), 605-612.

58. Svetlik, I., and Stavrou-Costea, E. (2007). Connecting human resources management and knowledge management. International. Journal of Manpower, 28(3/4), 197-206.

59. Swuste, P., Frijters, A., and Guldenmund, F. (2012). Is it possible to influence safety in the building sector?: A literature review extending from 1980 until the present. Safety Science, 50(5), 1333-1343.

60. Tan, H. C., Carrillo, P. M., and Anumba, C. J. (2011). Case study of knowledge management implementation in a medium-sized construction sector firm. Journal of Management in Engineering, 28(3), 338-347.

61. Titas, D. (2013). Typical Solutions for the Construction Site Employees' Safety. Procedia Engineering, 57, 238-243.

62. United States Department of Labor (1926). Safety and health Regulations for Construction, Standard Number 1926. Occupational Safety and Health Administration. Recuperado de

https://www.osha.gov/pls/oshaweb/owasrch.search_form?p_doc_type $=$ STANDARDS\&p_toc_level $=1 \&$ p_keyvalue $=$ Construction.

63. Uslu, T., \& Çubuk, D. (2015). The effects of knowledge management and self-organization on organizational creativity: the mediating roles of corporate innovativeness and organizational communication. International Journal of Organizational Leadership, 4(4), 403-412.

64. Vinodkumar, M. N., and Bhasi, M. (2010). Safety management practices and safety behaviour: Assessing the mediating role of safety 
knowledge and motivation. Accident Analysis \& Prevention, 42(6), 2082-2093.

65. Yamin, S. C., Parker, D. L., Xi, M., \& Stanley, R. (2017). Self-audit of lockout/tagout in manufacturing workplaces: A pilot study. American Journal of Industrial Medicine, 60(5), 1-6.

66. Zwetsloot, G. I. J. M. (2009). Prospects and limitations of process safety performance indicators. Safety Science, 47(4), 495-497. 